\title{
INTEGRATION OF THE ADIWIYATA SCHOOL PROGRAM TO REALIZE A SUSTAINABLE DEVELOPMENT GOALS (SDGs) IN SURAKARTA Bambang Partono $^{1^{*}}$, Ravik Karsidi ${ }^{2}$, Munawir Yusuf ${ }^{3}$, Soetarno Joyoatmojo ${ }^{4}$, Ryzal Perdana ${ }^{5}$ ${ }^{1}$ Student of Doctoral Program, Universitas Sebelas Maret, Jl. Ir. Sutami 36A Kentingan, Jebres, Surakarta, Indonesia; ${ }^{2,3,4,5}$ Lecturers of Pascasarjana, Universitas Sebelas Maret, J1. Ir. Sutami 36A Kentingan, Jebres, Surakarta, Indonesia. Email: ${ }^{1 *}$ bambang.partono@gmail.com, ${ }^{2}$ ravik@ staff.uns.ac.id, ${ }^{3}$ munawir_uns@yahoo.co.id, ${ }^{4}$ strn_jo@yahoo.co.id, ${ }^{5}$ ryzalperdana2009@gmail.com
}

Article History: Received on $24^{\text {th }}$ March 2020, Revised on $24^{\text {th }}$ April 2020, Published on $16^{\text {th }}$ May 2020

\begin{abstract}
Purpose of the study: The purpose of this research is to find out whether the Adiwitaya school program implemented in Surakarta has been integrated with the objectives of Sustainable Development Goals (SDGs).

Methodology: The method used is qualitative research, where researchers want to know the Adiwiyata program and school curriculum. Stages of research carried out through two stages, namely: in the first stage by collecting data in the field through observation, in-depth interviews, and documentation.

Main Findings: The results of the research and discussion based on the four aspects reviewed showed that waste management in Adiwiyata schools still needs to be improved. Increased knowledge, attitudes, and skills can be through instilling the values of sustainable development transferred through environmental education.

Application of this study: The implementation of research results can be used as input for policyholders within the scope of the minister of education and culture, and the minister of the environment so that the Adiwiyata program can be improved.
\end{abstract}

Novelty/Originality of this study: The renewal of this research is to analyze the objectives of the adiwiyata program as part of realizing sustainable development goals. The Adiwiyata school program implements Environmental Education in the syllabus and lesson plans.

Keywords: Pedagogy, Curriculum, Adiwiyata, School Program, SDGs, Environmental Education.

\section{INTRODUCTION}

Education is one of the main priorities carried out by the Indonesian government. This is intended so that the Indonesian state can become a developed country, so that it requires quality human resources, namely by promoting the quality of education (Ali F., Zhou Y., Hussain K. \& Neethiahnanthan N., 2016; Juwariyah, H, \& Latifah, 2017). The quality of education that needs to be considered not only in terms of physical development but also must be balanced with non-physical development including building student character (Kamaruddin, 2012). This is because the ability to think planted in schools has a significant correlation to the student's character education (Affandy, Aminah, \& Supriyanto, 2019). Character education that can be instilled in students consists of 6 dimensions, namely: (1) Appreciating Achievement, Friendly, Peaceful Love, Environmental Care and Responsibility; (2) Religious and living in harmony; (3) Honesty; (4) Creativity and Innovation; (5) Tolerance and Diversity; and (6) Discipline (Affandy, Aminah, \& Supriyanto, 2019).

Integrated character education in subjects can be seen from the model (Tsai, 2012) of the learning implementation plan (RPP) made by the teacher. However, the problem that arises is that teachers are still experiencing difficulties in training character through learning activities (Tsai, 2012). Especially on the character of caring for the environment (Kamaruddin, 2012; Tsai, 2012). The rapid development of science and technology, supporting the development of infrastructure to support human life (Ekawati, 2017). Unfortunately, the progress of development is not accompanied by the character of caring for the environment, resulting in environmental degradation including pollution and environmental damage.

Science should be able to preserve and preserve the environment, but due to the massive exploitation of natural resources, population growth, and social activities without regard to environmental carrying capacity (Rodrigues, 2014; UNESCO, 2011). This has caused deterioration in environmental quality and pollution (Maryani, 2014). Based on this phenomenon, various policies that have been implemented by the government in education, are intended to participate in protecting the environment through the Adiwiyata school program (Maryono, 2015). The implementation of the Adiwiyata school program began in the 2000s, which was initiated by a collaboration between the Environment Agency (in Indonesia Badan Lingkungan Hidup, BLH) and the Education Office to open registration for schools that participated in the Adiwiyata school selection. Schools selected from the selection results are then given counseling guided by BLH and the education office. In the Adiwiyata Program, four aspects must be met to be able to meet the criteria as an Adiwiyata school. Among them, environmentally friendly policies, environment-based school curriculum, participatory activities, and management of environmentally friendly supporting facilities (Maryani, 2014). 
Adiwiyata School is one part of the Sustainable Development Goals (Mahat, Hashim, Nayan, Saleh, \& Norkhaidi, 2018). SDGs has been integrated into many global frameworks and conventions that are related to the main areas of sustainable development, that framework is climate change, biodiversity, disaster risk reduction, and sustainable production (UNESCO, 2011).

\section{LITERATURE REVIEW}

The Earth system in the environment has many natural resources to come with all kinds of living creatures' needs. It is in line with the time, the pace of technological development, and human needs growth. Greedy human traits that are always never satisfied, have an impact on the environment and existing natural resources. Environmental problems that have occurred in the last few decades, show very alarming things. The problems that occur are (1) pollution, (2) deforestation, (3) land loss, (4) ozone depletion, (5) global warming, (6) to significant climate change. (Anggraini \& Karyanto, 2019).

Adiwiyata School uses learning as a way to direct students to achieve success as the main school in environmental preservation that is sustainable. Pedagogic is an inseparable part of learning (Shulman, 1986), where adiwiyata schools are also implemented in learning. Pedagogy is used so that learning is planned in a clear direction and stages. The teacher factor is one of the keys to success in the learning process because the teacher is a source of learning. As a professional teacher must have good pedagogy competence because it has a significant influence on teacher performance (Masrifah, Setiawan, Sinaga, \& Setiawan, 2019; Shulman, 1986). The government has made efforts to improve teacher professionalism through various in-house seminars and training, to improve pedagogical competence and teacher professionalism.

\section{RESEARCH PROBLEM}

Based on the problem that has been explained, through this article the researcher wants to know the Adiwiyata pedagogy and curriculum program, within the framework of the SDGs. Given the implementation of the Adiwiyata program is one of the conditions in which schools become a place of learning and awareness of school residents. It is intended that in the future school residents (teachers, students, and other workers) can participate in various efforts to save the environment and sustainable development.

\section{METHODS}

\section{Research Design}

The method used in this research is a qualitative descriptive study, in which the researcher wants to know whether the adiwiyata program implemented has achieved the Sustainable Development Goals (SDGs). Descriptive research methods aim to describe, explain, and validate social phenomena that are the object of research (Sugiyono, 2013). The phenomenon that is the object of this research is the adiwiyata program, which has been run by schools in Surakarta as an effort towards sustainable development goals.

\section{Instrument and Procedures}

The procedure used consisted of two stages, namely the first stage by collecting data using a non-test instrument (Mardapi, 2012) in the form of a questionnaire, in-depth interviews, and documentation. Analysis of documentation only on lesson plans (RPP) made by teachers. Research instruments are tools that are used by researchers to collect research data (Sugiyono, 2013). The non-test instrument in the form of a questionnaire consists of four aspects, namely (1) environment based curriculum, (2) waste management, (3) management of clean water management, and (4) food and drinks in the school environment. As for the indicators on each aspect, the details are presented in Table 1.

Table 1: Aspects and Indicators of non-test instruments

\begin{tabular}{ll}
\hline Aspect & Indicator \\
\hline \multirow{2}{*}{ Environment based curriculum } & Models, methods, and learning strategies \\
\cline { 2 - 2 } Waste management & The quality of human resources in environmental management \\
\hline \multirow{2}{*}{ Water Sanitation and Management } & Distribution of types of waste \\
\cline { 2 - 2 } & Waste management \\
\hline \multirow{2}{*}{ Food and drinks in the school environment } & Education and training \\
\cline { 2 - 2 } & Knowledge of chemicals in food \\
\hline
\end{tabular}




\section{Source: (Sugiyono, 2013)}

The second stage is to conduct a literature study by analyzing data sources in the form of books, journal articles, and publication articles from existing research results. The purpose of this literature study is to compare, the results of field research with the concepts proposed by experts that have been published. The subjects involved in this study were several teachers and as many as 100 high school students in Surakarta. There are 3 schools involved, where the selected schools are schools that have received national, provincial, and city Adiwiyata located in Surakarta city, Central Java province, Indonesia which promotes their school by eco- friendly perspective as the base for the sample selection.

\section{Data Analysis}

The data analysis method used is a descriptive analysis technique that is tailored to the purpose of the research that is trying to describe the data as it is (Sugiyono, 2013). Data analysis is an activity to process data from respondents, using instruments. Descriptive percentage analysis is a method used to describe each aspect, namely (1) environment based curriculum, (2) waste management, (3) management of clean water management, and (4) food and drinks in the school environment. The alternative answers provided by each question include 4 score categories, namely a score of 4 is strongly agree, a score of 3 agrees, a score of 2 is disagree, and a score of 1 strongly disagrees. Alternative answers are chosen using 4 criteria, this is because if given 5 criteria there is a tendency of respondents to choose answers in the middle (neutral or moderate) (Mardapi, 2012).

\section{RESULT}

Characteristics of the Adiwiyata school-based environmental curriculum in high schools and vocational schools are the implementation of Environmental Education in the syllabus and Learning Implementation Plans (RPP). The results of descriptive data analysis on each aspect are presented in Figure 1.

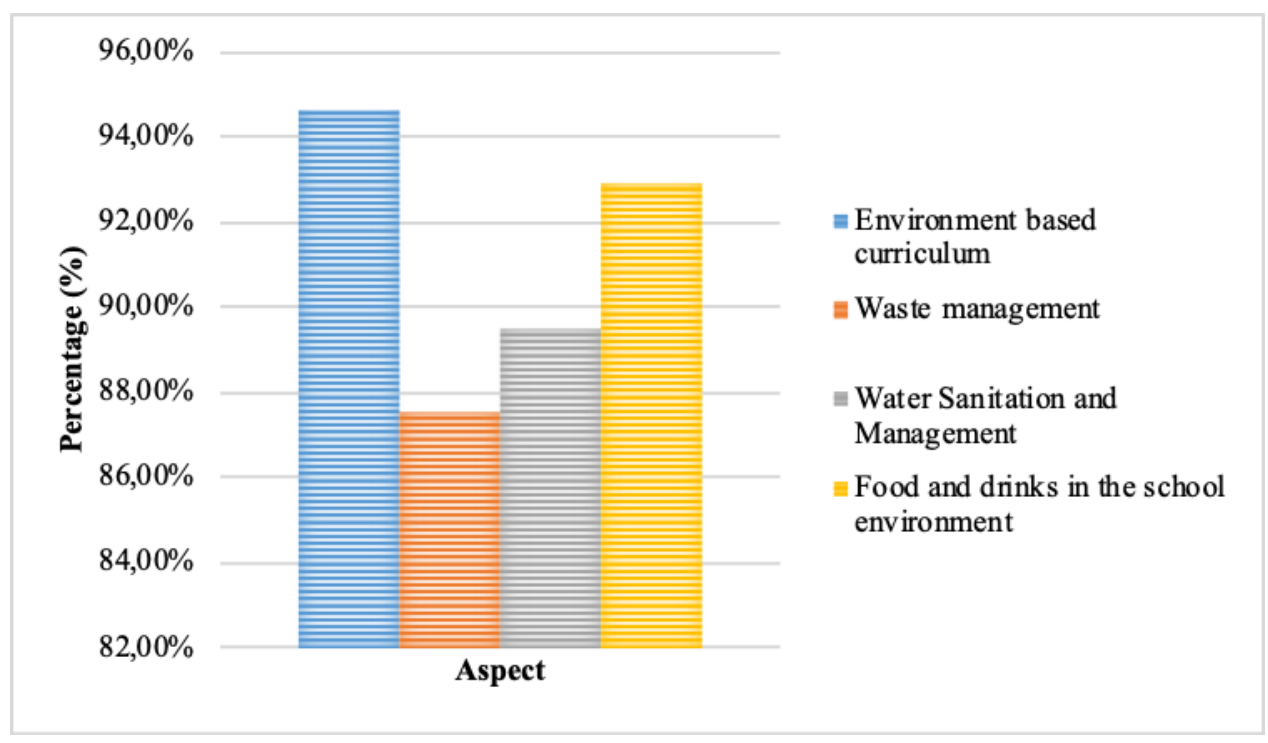

Figure 1: Descriptive data analysis results on every aspect of the adiwiyata program

Source: (Processed Data Results, 2019)

The results of the study based on four aspects reviewed showed that waste management in Adiwiyata schools still needs to be improved. This also relates to the goals of sustainable development (SDGs), namely protecting, restoring, and supporting the sustainable use of terrestrial ecosystems, managing forests sustainably, combating desertification, and inhibiting and reversing land degradation and inhibiting loss of biodiversity. The results of the analysis of syllabus documentation and lesson plans in schools, only $53.33 \%$ to $80 \%$ of subjects have integrated environmental education from 15 subjects. This means that only a few Adiwiyata school teachers understand the purpose of the adiwiyata school which is towards sustainable development. The results of the analysis of waste management in schools indicate that schools have not provided education and training in waste management. The complete response results are presented in Table 2.

Subjects integrated with environmental education are limited to normative and adaptive subjects. This result is consistent with the results of Muflihaini's research (2019) which states that learning should be based on the syntax that has been presented in the syllabus of subjects and arranged in the RPP can be integrated with the objectives of sustainable development., ecosystems, and changes in environmental impacts (Muflihaini \& Suhartini, 2019). While the results of observations in certain vocational schools, productive subjects do not combine environmental education materials. Besides, 
there is also local content in environmental education subjects that are carried out monolithically in each school.

Table 2: Respondents' responses are reviewed in terms of the Adiwiyata program

\begin{tabular}{lllll}
\hline Indicator & $\begin{array}{l}\text { Strongly } \\
\text { agree }\end{array}$ & Agree & Disagree & $\begin{array}{l}\text { Strongly } \\
\text { disagree }\end{array}$ \\
\hline Models, methods, and learning strategies & $82 \%$ & $10 \%$ & $5 \%$ & $3 \%$ \\
\hline $\begin{array}{l}\text { The quality of human resources } \\
\text { environmental management }\end{array}$ & in & & & \\
\hline Distribution of types of waste & $75 \%$ & $7 \%$ & $2 \%$ & $1 \%$ \\
\hline Waste management & $70 \%$ & $12 \%$ & $11 \%$ & $7 \%$ \\
\hline Knowledge of the water cycle & $73 \%$ & $12 \%$ & $9 \%$ & $6 \%$ \\
\hline Education and training & $78 \%$ & $12 \%$ & $6 \%$ & $4 \%$ \\
\hline Knowledge of chemicals in food & $81 \%$ & $11 \%$ & $5 \%$ & $3 \%$ \\
\hline Health food management & $83 \%$ & $10 \%$ & $4 \%$ & $3 \%$ \\
\hline
\end{tabular}

Source: (Processed Data Results, 2019)

\section{DISCUSSION}

\section{Adiwiyata Program School Model}

Adiwiyata is one of the Ministry of Environment's programs to encourage the creation of knowledge and awareness of school residents in environmental conservation efforts (Hidup, 2013; Syafrudie, 2019). In participatory activities, all school components are expected to actively participate in environmental action activities carried out by non-school plaques, build partnerships (government, private, and Non-Government Organizations, NGOs) in the development of environmental education, and can create extracurricular/curricular activities that support the development of environmental education (Syafrudie, 2019). So it can be said that the Adiwiyata program is one of the initial prevention efforts to anticipate environmental pollution and damage even more widely (Prihartono, Azhar, \& Danhas, 2019).

The development and management of school support facilities is also an important indicator that must be considered. Activities undertaken may take the form of developing the quality functions of school support facilities; improving the quality of environmental management within and outside the school area, including sanitation, school canteens; increasing efforts to save energy, water, stationery; development of waste management systems; as well as the development of life pharmacies and school parks, considering that at this time, land, water, sea, forest and biodiversity are being degraded rapidly. As a result, climate change is putting pressure on more resources, thereby increasing the risk of natural disasters (such as drought and floods) (Zongsheng et al., 2019). The aim of the Adiwiyata program is generally to make school members responsible for protecting and managing the environment through good school governance to support sustainable development. Adiwiyata has the understanding as a good and ideal place where all knowledge and various norms and ethics can be obtained that can be the basis of humans towards the creation of our welfare and towards the framework of SDGs (Mahat et al., 2018; Maryani, 2014). Sustainable development is defined as a process that aims to meet the needs of the current generation without hurting the ability of future generations. This means that everything or activity that we have today will also be owned and enjoyed by future generations. Also, in Education for Sustainable Development Goals (SDGs) designed at the end of the Decade for Sustainable Development Education, United Nations (2007) expressed the goal of sustainable development as a sustainability activity that must be continued by future generations.

The application of the Adiwiyata school program has criteria seen from its components and standards, including (Yanti Dwi Rahmah, Indradi, \& Riyanto, 2014): Environmentally sound policies and planned activities and school budgets which are applied within the scope of the school in the form of a vision, mission, and goals of the school that contain efforts to protect and manage the environment, Implementation of an environment-based curriculum where the teacher or educator is competent so that in the delivery of environmental learning can be understood and implemented by students. Participatory-based environmental protection activities Management of environmentally friendly supporting facilities in the provision of infrastructure in the form of paving blocks, green open spaces or greenhouses, and recycling sites.

Based on components and standards in the Adiwiyata school program, it is often referred to as the green school program. The quality of management and life protection have constraints in efforts to improve it, namely the ongoing renovation of the building has damaged infrastructure, and there is still the use of plastic in food packaging in the school canteen. Besides, the school canteen still sells instant noodles which are fast food and uses plastic in its packaging. So this is not by the 
components in the Adiwiyata school program.

In other words, the basic principles of the Adiwiyata Program are a place to stand and bring up a point of view that contains 3 principles. The three basic principles are (1) educative, (2) participatory, and (3) sustainable. The first principle is education. This means that in the Adiwiyata Program, implicitly does not only contain the meaning of mere knowledge. But more than that, that education is broad and reaches the level of behavior change. Explicitly is the implementation of the Adiwiyata Program, which means bringing about a change in behavior. Changes in behavior, based on faith, science, and art. This is also following the concept of character education (Affandy et al., 2019), which is to be achieved in the national education curriculum.

The second principle is participatory. Participatory refers to a manifestation of participatory activities. Where participation is a verb that refers to the form of activities/actions/activities. Thus, in the Adiwiyata Program, all components contained within the scope of participation activities (voluntary participation). The third principle is sustainability. Sustainability means uninterrupted or non-stop. The meaning of sustainability in the context of development means making a situation where environmental resources can always sustain the development process between generations. In this case, the Adiwiyata Program is packaged as a program that will not never stop or disconnected. So the subject involved is all human resources in the school environment. It can be said that the Adiwiyata Program with the three principles it contains is one of the instruments in environmental protection and management in the country.

\section{Adiwiyata Program School Curriculum}

Natural Sciences is one branch of science that works to figure out any phenomena that occurred on this planet (Anggraini $\&$ Karyanto, 2019). Science learning in Indonesia is a compulsory subject taught in the level of education of primary and secondary. The current curriculum implementation in Indonesia is the 2013 curriculum, which emphasizes knowledge not only as a learning source for science but also firmly inserting values about attitudes from an environmental perspective.

Characteristics of the Adiwiyata school-based environmental curriculum in high schools and vocational schools are the implementation of Environmental Education in the syllabus and lesson plans. Environmental Education Materials are integrated into several subjects such as English, Natural Sciences, Religion, Social Sciences, Health. The environment-based curriculum is implemented in learning activities, for examples in English subjects are making a warning board or slogan about cleanliness and sanitation. Whereas in the Physical Education course, for example, teachers can integrate environmental education into learning activities by implementing learning by utilizing the environment as a learning resource. The implementation of an environment-based curriculum is also followed by supporting policies such as the development of planting various plants in the schoolyard, building greenhouses, and so on. Through the observation of objects in the school environment, students can learn about ecosystems and the interactions of living things that can be found in the school environment following the concept of biology (Muflihaini \& Suhartini., 2019).

The learning model used in implementing the Adiwiyata program-based curriculum is a cross-subject learning model. In addition to being implemented in the form of integration in subjects, environmental education materials are carried out through (a) group discussions; (b) writing a work; (c) conduct research; (d) field study; (e) environmental maintenance and preservation practices. Besides, curriculum development is carried out by providing counseling to teachers by presenting speakers from government institutions related to the environment.

Planning curriculum development is formulated based on the policies of Adiwiyata based on the Joint Decree of the Environment and the Minister of National Education. Organizing the development of environment-based curriculum related to organizational components, consisting of three components including the Adiwiyata team from the teacher, the student council Adiwiyata team, and the class motivator team, the environment-based curriculum material developed by the teacher Adiwiyata team by compiling environmental learning tools, in the form of syllabus and lesson plans.

The curriculum development can be carried out among others: (a) Development of cross-subject learning models; (b) Excavation and development of material and environmental problems that exist in the surrounding community; (c) Development of learning methods based on environment and culture; (d) Development of curricular activities to increase students' knowledge and awareness about the environment.

\section{Adiwiyata Program Pedagogy and Pedagogical Competency Objectives}

Pedagogic is an inseparable part of learning (Shulman, 1986), where Adiwiyata schools are also implemented in learning. Pedagogic is defined as a process of continuous interaction and mutual assimilation between scientific knowledge and student development (Shulman, 1986). Assimilation in question is the knowledge of students relating to the enthusiasm of students to find verified in an intensive and active work process. Pedagogical emphasis on aspects of teaching that is carried out continuously from the process of assimilation which is an intensive intellectual effort on students. Maintaining the overall teaching and education process and leading to the formation of students' personalities is one of the functions of Pedagogic. 
Pedagogy appears in every stage of learning. Beginning with the formulation of the substance that represents an understanding of students, the design of learning that appears in its stages, evaluation of learning outcomes, and direction of student development to actualize the various potentials they have. All of this appears in the Learning Implementation Plan (RPP) prepared by Adiwiyata School. Pedagogical competency objectives. The following are the objectives of pedagogical competence, as follows:

1. Humanize Humans; Humanizing human means to make someone mature for happiness in living life. In this case, it indicates that pedagogical competence aims to foster one's development so that he is prepared to live his life independently and be able to solve the problems he faces.

2. Understanding Identity: For students to be able to understand and live life in the future and be able to support themselves, be able to live meaningfully, and be able to glorify life. Not much different from the first goal is to prepare students to face their lives.

3. Practice Courage: Help students question and challenge dominance and dominating beliefs and practices. Pedagogic competence has the aim to train students to have courage. Courage to ask questions and find out answers to questions.

4. Developing Healthy Student Personalities; In this case, it means that pedagogical competence has a goal to develop student personality. The personality in question is a good personality that helps him prepare for life.

\section{Benefits of Pedagogical Competence}

The benefits of pedagogical competence when viewed from the perspective of the principal/teacher and students, namely: the teacher can understand the characteristics, character, level of thought, physical and psychological development of students (Desfandi, Maryani, \& Disman, 2017). With this understanding, teachers can easily understand the difficulties and ease of students in learning and developing themselves so that teachers can more easily help students develop (Fadlilah \& Ngabekti, 2018). So that it can be used as a guide to finding out which direction and goals to be achieved. Pedagogical competence can help teachers in determining the goals and directions of the learning being done

The teacher can avoid or at least reduce errors in practice because by understanding the theory of education, a teacher can know what is and is not allowed to be done, even though the theory is not a telling recipe. Pedagogical competence can be used as a benchmark, to the point where someone has successfully carried out tasks in education. While students can be fulfilled their curiosity. Because teachers must be able to arouse and manage children's curiosity in every learning activity. The teacher not only tells stories or explains subjects but also stimulates students' critical thinking skills through questioning and testing skills.

Students dare to think and the ability to solve problems. Then the teacher must be able to use teaching methods that make students actively argue or answer a variety of questions/problems of knowledge complete with the reasons. Students feel happy in their learning activities. The teacher must respect the imagination of students, cultivate tolerance, enter the nuances of education with humor and develop the talents of students, even though students have weaknesses in one or a variety of subjects. Thus students will have the confidence and feelings of worth from the outstanding talent or ability they have. Examples of pedagogical competencies include: (1) Teachers use various methods and models in learning, such as discussions, lectures, jigsaws, pairs. This is an effort to enliven learning and students actively participate; (2) The teacher provides space for students to express opinions in front of the class. This is to train students' courage and accommodate student activity. Students need to have the courage to express their opinions so that when they are in the community they can participate in community activities; (3) The teacher uses various media in learning such as teaching aids, puzzles, videos, and others. This is an effort to maximize the material being taught. And differences in student characteristics also become a facilitator so that teachers can use various learning media.

Based on the results of field studies and literature review taking into account sustainability planning, the Adiwiyata program school organizers had the opportunity to minimize the potential for negative impacts, given a large number of stakeholders involved. In other words, the Adiwiyata program school concretely influences environmental changes better and might inspire those involved to be able to live more sustainably (Buathong \& Lai, 2019; Setiawan, 2016).

\section{CONCLUSION}

The results of the research and discussion based on the four aspects reviewed showed that waste management in Adiwiyata schools still needs to be improved. Increased knowledge, attitudes, and skills can be through instilling the values of sustainable development transferred through environmental education so that students are responsible for future sustainability. The Adiwiyata school program implements Environmental Education in the syllabus and lesson plans. Submission of environmental material to students is done through an integrated curriculum in several subjects, namely English, Natural Sciences, Religion, Social Sciences, and Physical Education. The results of the analysis of waste management in schools show that schools have not yet provided waste management education and training. This also 
relates to the goals of sustainable development (SDGs), which are protecting, restoring, and supporting the use of sustainable terrestrial ecosystems, managing forests sustainably, combating desertification, and inhibiting and reversing land degradation and inhibiting loss of biodiversity. The learning model used in environment-based learning is a cross-subject model. To find out the success in curriculum development can be obtained through supervision activities. The Adiwiyata program with the principles of education, participation, and sustainability is one of the instruments in environmental protection and management in this country.

\section{LIMITATION AND STUDY FORWARD}

It is recommended for future research to validate the impact of the Adiwiyata award for school on waste management into broadening aspects from an environmental point of view. It is also necessary to measure the eco- friendly standard not only relying on the disposal management but also include all related supporting factors to get in line with the Sustainable Development Goals (SDGs).

\section{ACKNOWLEDGMENT}

First author; making the article's draft, arranging graph, the paper revision to the final manuscript. Second author: critically revise the basis content for essential matter on the draft of the article. Third author: data analysis and interpretation. Fourth and five authors: setting the main concept of the framework and data design.

\section{REFERENCES}

1. Affandy, H., Aminah, N. S., \& Supriyanto, A. (2019). The correlation of character education with critical thinking skills as an important attribute to success in the $21^{\text {st }}$ century. Journal of Physics: Conference Series, 1153(1). https://doi.org/10.1088/1742-6596/1153/1/012132

2. Ali F., Zhou Y., Hussain K., K. P., \& Neethiahnanthan N., R. A. (2016). Quality Assurance in Education. Quality Assurance in Education, 24(1), 7-94. https://doi.org/10.1108/QAE-02-2014-0008

3. Anggraini, W., \& Karyanto, P. (2019). School and Teachers ' Role to Empowerment of Environmental Literacy in Prominent Middle School-Based on Adiwiyata Program School and Teachers ' Role to Empowerment of Environmental Literacy in Prominent Middle School-Based on Adiwiyata Program. IOP. Conf. Series: Journal of Physics: Conf. Series, 1233, 1-8. https://doi.org/10.1088/1742-6596/1233/1/012084

4. Buathong, K., \& Lai, P.-C. (2019). Event sustainable development in Thailand: A qualitative investigation. Journal of Hospitality, Leisure, Sport \& Tourism Education, 24(June 2019), 110-119. https://doi.org/10.1016/j.jhlste.2019.02.001

5. Desfandi, M., Maryani, E., \& Disman. (2017). Building Ecoliteracy Through Adiwiyata Program (Study at Adiwiyata School in Banda Aceh). Indonesian Journal of Geography, 49(1), 51-56. https://doi.org/10.22146/ijg.11230

6. Ekawati, E. Y. (2017). A model of scientific attitudes assessment by observation in physics learning-based scientific approach: a case study of the dynamic fluid topic in high school. Journal of Physics: Conference Series, 755(1). https://doi.org/10.1088/1742-6596/755/1/011001

7. Fadlilah, U., \& Ngabekti, S. (2018). Education The Adiwiyata School's Role in the Development of Character Caring for the Environment ( A Case Study at the Junior High School 6 Tuban ). Journal of Innovative Science, $7(1), 53-61$.

8. Hidup, M. L. (2013). Peraturan Mentri Lingkungan Hidup Republik Indonesia: Program Adiwiyata.

9. Juwariyah, S., H, S. K., \& Latifah, E. (2017). Guided Inquiry Method Employing Virtual Laboratory to Improve Scientific Working Skills. JPS (Jurnal Pendidikan Sains), 5(1), 17-25. https://doi.org/10.17977/jps.v5i1.9016

10. Kamaruddin, S. A. (2012). Character Education and Student's Social Behavior. Journal of Education and Learning, 6(4), 223-230. https://doi.org/10.11591/edulearn.v6i4.166

11. Mahat, H., Hashim, M., Nayan, N., Saleh, Y., \& Norkhaidi, S. B. (2018). Mapping of Student Sustainable Development Education Knowledge in Malaysia using Geographical Information System ( GIS ). 8(1). https://doi.org/10.5430/wje.v8n1p27

12. Mardapi, D. (2012). Pengukuran, Penilaian, dan Evaluasi Pendidikan. Yogyakarta: Nuha Litera.

13. Maryani, I. (2014). EVALUASI PELAKSANAAN PROGRAM SEKOLAH ADIWIYATA. Jurnal Pemikiran Dan Pengembangan SD, 1(3), 225-229.

14. Maryono. (2015). The Implementation of the Environmental Education at "Adiwiyata" Schools in Pacitan Regency (An Analysis of the Implementation of Grindle Model Policy). Journal of Education and Practice, 6(17), 31-42.

15. Masrifah, M., Setiawan, A., Sinaga, P., \& Setiawan, W. (2019). The content quality of teacher's pedagogical and professional competence standards of senior high school physics teacher guide books. Journal of Physics: 
Conference Series, 1157(3), 1-8. https://doi.org/10.1088/1742-6596/1157/3/032037

16. Muflihaini, M. A., \& Suhartini. (2019). Implementation of environmental care character education value on biology subject through adiwiyata Implementation of environmental care character education value on biology subject through adiwiyata. IOP. Conf. Series: Journal of Physics: Conf. Series, 1241(012028), 1-10. https://doi.org/10.1088/1742-6596/1241/1/012028

17. Prihartono, A. T., Azhar, A., \& Danhas, Y. (2019). Implementation strategy character building of care and environmental culture in school Implementation strategy character building of care and environmental culture in school. IOP. Conf. Series: Journal of Physics: Conf. Series, 314(012052), 1-10. https://doi.org/10.1088/1755-1315/314/1/012052

18. Rodrigues, S. J. (2014). Environmental Education: A Propose of High School. Procedia - Social and Behavioral Sciences, 116, 231-234. https://doi.org/10.1016/j.sbspro.2014.01.199

19. Setiawan, A. S. J. N. K. R. W. B. (2016). The Development of Integrated and Adiwiyata-Based Thematic Textbooks for the Fourth Graders Of primary Schools in Ngawi Regency, East Java, Indonesia. International Journal of Science and Research (IJSR), 5(8), 1688-1693. https://doi.org/10.21275/ART20161225

20. Shulman, L. S. (1986). Those Who Understand: Knowledge Growth in Teaching. American Educational Research Association, 15(2), 4-14. https://doi.org/10.3102/0013189X015002004

21. Sugiyono. (2013). Metode Penelitian Kuantitatif dan $R \& D$. Bandung: Alfabeta.

22. Syafrudie, H. A. (2019). Community-based school improvement : a case study in Adiwiyata School at Malang Community based school improvement: a case study in Adiwiyata School at Malang. IOP. Conf. Series: Journal of Physics: Conf. Series, 1-6. https://doi.org/10.1088/1755-1315/245/1/012022

23. Tsai, K. C. (2012). Bring character education into the classroom. European Journal of Educational Research, 1(2), 163-170. https://doi.org/10.12973/eu-jer.1.2.163

24. UNESCO. (2011). National Journeys: towards Education for Sustainable Development. Paris, France: United Nations Decade of Education for Sustainable Development 2005-2014.

25. Yanti Dwi Rahmah, Indradi, S. S., \& Riyanto. (2014). IMPLEMENTASI PROGRAM SEKOLAH ADIWIYATA ( Studi pada SDN Manukan Kulon III / 540 Kota Surabaya ). Jurnal Administrasi Publik, 2(4), $753-757$.

26. Zongsheng, H., Lan, J., Wang, Z., Zeng, R., Xu, D., \& Liu, J. (2019). The emergy analysis of southern China agro-ecosystem and its relation with its regional sustainable development. Global Ecology and Conservation, 20(e00721), 1-11. https://doi.org/10.1016/j.gecco.2019.e00721 